\title{
Orina púrpura.
}

\section{Purple urine.}

\author{
Jonathan Barraza ${ }^{1}$
}

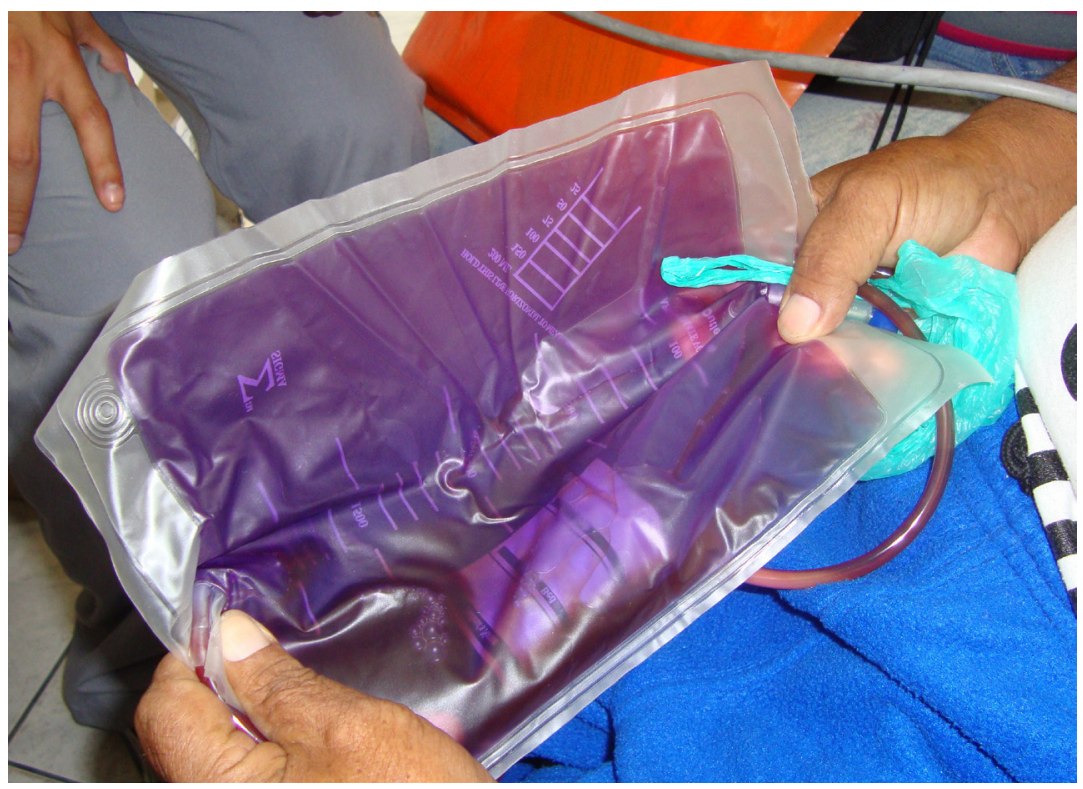

Varón de 73 años, con enfermedad renal crónica terminal en terapia de hemodiálisis, portador de catéter vesical desde hace 8 meses por hiperplasia benigna de próstata. Acudió a la consulta ambulatoria con historia de orina de color púrpura con abundante detritus de un mes de evolución. El examen de orina mostró pH 8, leucocitos 8-10 x campo y hematíes 16-18 x campo y se aisló Enterococcus faecalis $>10^{5} \mathrm{UFC} / \mathrm{ml}$. La degradación por enterobacterias (Providencia, Klebsiella, P. aeruginosa, Enterococcus) del indoxil sulfato (indicano), un producto del metabolismo del triptófano de la dieta que se elimina por la orina, dependiendo del pH producirá índigo (azul) e indurubina (rojo), la combinación de ambos nos dará orina púrpura.

A 73 year-old male previously diagnosed of chronic renal failure and benign prostatic hyperplasia on hemodialysis and with a urinary catheter for the last 8 months presented with purple urine and significant detritus of one-month duration. Urine examination showed a pH of 8; 8-10 white blood cells per field, and 16-18 red blood cells per field. Enterococcus faecalis was isolated from the urine (> $105 \mathrm{CFU} / \mathrm{ml})$. Degradation of indoxyl sulphate, a product of tryptophan metabolism, by Enterobacteria (Providencia, Klebsiella, P. aeruginosa, Enterococcus) stains the urine of red and blue depending on the $\mathrm{pH}$, the combination of these colors cause the purple aspect of the urine.

1. Médico residente $4^{\circ}$ año. Servicio de Nefrología, Hospital Nacional Cayetano Heredia. Universidad Peruana Cayetano Heredia. Lima, Perú. 